\title{
ANALISIS PERAN PEREMPUAN DALAM PENGELOLAAN SAMPAH RUMAH TANGGA (STUDI PADA MASYARAKAT KOTA BATU)
}

\author{
ANALYSIS OF THE ROLE OF WOMEN IN MANAGING \\ HOUSEHOLD WASTE (STUDY IN THE COMMUNITY OF BATU \\ CITY)
}

Uci Yuliati ${ }^{1)}$

${ }^{1)}$ Universitas Muhammadiyah Malang. Jln. Raya Tlogomas No. 246, Malang. Telp. (0341) 464318-319 Fax 0341460435.

\begin{abstract}
Abstrak: Penelitian ini dilakukan di Kota Batu. Wanita dalam rumah tangga adalah responden dari penelitian ini. Penelitian ini sangat penting dilakukan karena perempuan masih mendominasi kegiatan pembersihan rumah di masyarakat Indonesia. Oleh karena itu, sangat menarik untuk mengetahui secara mendalam tentang aktivitas, akses dan kontrol, profil manfaat dan dampaknya saat mereka membersihkan sampah rumah tangga. Sampling area total terdiri dari tiga kecamatan dan responden dipilih secara purposif dengan kriteria yang merupakan wanita sebagai ibu di rumah tangga. Jumlah responden adalah 73 wanita. Kuesioner digunakan sebagai instrumen pengumpulan data. Program SPSS adalah analisis data untuk memiliki berbagai tabulasi lintas profil di atas. Hasil analisis menunjukkan bahwa profil kegiatan perempuan dapat dikelompokkan ke dalam aktivitas mereka dari limbah rumah tangga yang dihasilkan sampai bagaimana pembersihan rumah mereka dari limbah. Pengkajian dan pengendalian profil menunjukkan bagaimana mereka mengelola limbah rumah mereka, bagaimana memilihnya dan membuangnya ke tempat pembuangan sampah lalu bagaimana mereka mengkomunikasikan kesulitan mereka kepada Waste Local Collector. Dampaknya dan profil yang menguntungkan menunjukkan dampak ekonomi mereka dengan memilih, memisahkan dan mengumpulkan rumah-menyimpan limbah padat. Hasil penelitian menunjukkan bahwa sebagian besar wanita memproduksi rumahmenyimpan sampah dari memasak di dapur mereka. Wanita biasa mengelola sampah rumah tangga dari menyediakan kotak atau kantong plastik, sapu, lalu untuk membersihkan dan mengumpulkannya dan kemudian membuangnya ke tempat jauh dari rumah di pembuangan sampah. Mereka biasa membersihkan rumah mereka setiap hari dan kadang suami dan anak mereka membantunya. Wanita sering memisahkan sampah padat dan kering padat, bisa jadi sampah yang bermanfaat yaitu botol plastik atau gelas dan kertas. Setelah memisahkannya, sampah dikumpulkan dan kemudian menjualnya untuk mendapatkan uang.
\end{abstract}

Kata kunci : Limbah Rumah, perempuan, kegiatan pengelolaan limbah padat, akses dan pengendalian limbah padat, dampak dan limbah padat.

\begin{abstract}
This research was carried out in Batu City. Women in the house-holds were the respondents of this research. This research was very important to be done because women were still dominating the cleaning activities at home in Indonesian society. Therefore it was interesting to learn deeply about their activities, access and control, beneficial and impact profiles while they were cleaning house-holds waste.Total area sampling consists three sub-district and respondents were chosen purposively with its criterions who were women as mother in the households. The number of respondents were 73 women. Questionnaires were used as an instrument for data collecting. SPSS program was the data analyses for having the cross-tabulation various profiles above. The result of analyses shown that women activities profile could be classify in to their activities from resulting household waste until how they were cleaning their home from waste. Access and control profile shown how they were managing their home waste, how to select it and throw it away to dumpsite then how they communicated their difficulties to Waste Local Collector.The impact and beneficial profile shown what they had economic impact by selecting,
\end{abstract}


separating and collecting house-holds solid waste. The result of research shows that most of women produced household waste from cooking in their kitchen. Women used to manage household waste from providing boxes or plastic bags, broom, and then to sweep and to collect it and then through away from home to dumpsite.They used to clean their home from waste everyday and sometimes their husbands, daughter and son help them. Women who often separate from wet and dry solid households waste could find out the beneficial one namely plastic or glass bottle and paper. After separating it, women collected and then sold it after a few time for earning money.

Keywords: Household waste, women, solid waste management activities, access and control solid waste, impact dan beneficial solid waste.

\section{PENDAHULUAN}

Kenyataan menunjukkan bahwa sekarang Batu sudah menjadi sebuah kota. Siapapun apabila mendengar istilah kota pikirannya pasti akan terbayang sesuatu keadaan daerah dengan segala sesuatu yang serba modern, professional dan gemerlap. Keadaan daerah kota secara umum memiliki berbagai macam perbedaan dengan daerah desa. Dalam perkembangannya barangkali hal demikian sangat diharapkan. Namun harapan itu akan sirna apabila pengelola kota dalam hal ini Pemerintah Kota (Pemkot) tidak dapat menjalankan tugas secara profesional dan terintegrasi. Tugas Pemerintah Kota antara lain mengatur berbagai sektor ekonomi mulai dari sektor pertanian sampai dengan sektor jasa-jasa. Dalam pengelolaan berbagai sektor yang ada pemerintah memperhatikan penataan keindahan kota. Salah satu aspek penting dalam penataan kota secara fisik seperti jalan-jalan, trotoar, penempatan gedung-gedung perkantoran, pabrik-pabrik dan sebagainya.

Pelaku ekonomi selain pemerintah sebagai mencakup perusahaan-perusahaan dan masyarakat yang keberadaannya terutama perilakunya sangat perlu diperhatikan. Perilaku mereka akan tampak dari kegiatan yang dilakukannya. Efek samping hasil kegiatan yang dilakukan para pelaku ekonomi pada berbagai sektor di atas adalah adanya sampah. Sistem pembuangan sampah ini apabila tidak dikelola secara profesional akan mengganggu keindahan dan kesehatan lingkungan kota. Sampah sebagai kotoran yang dihasilkan oleh masyarakat rumah tangga, perusahaan maupun pemerintah dapat dibedakan menjadi dua macam, yaitu sampah cair (liquid waste) dan sampah padat (solid waste). Sampah cair merupakan limbah yang biasanya dihasilkan oleh industri manufaktur yang banyak menggunakan bahan kimia. Biasanya untuk membuang limbah cair ini perusahaan harus terlebih dahulu melakukan penetralan (netralisasi) agar tidak merusak lingkungan apabila limbah cair ini dibuang kedalam aliran sungai. Sedangkan sampah padat atau sering disebut limbah padat apabila tidak dikelola secara profesional juga akan sangat mengganggu lingkungan baik dari segi kesehatan maupun keindahan dan kebersihan kota.

Apabila dilihat dari proses terjadinya sampah padat maupun cair sampai bagaimana dan di mana menempatkannya sehingga tidak mengganggu lingkungan memang sangat panjang. Pemerintah kota jangan hanya terjebak pada permasalahan bagaimana dan di mana sampah akan dibuang tetapi hendaknya berpikir darimana sampah berasal dan siapa yang dapat diperankan agar proses pengelolaan selanjutnya akan lebih mudah bahkan dapat menguntungkan pemerintah daerah. Apabila seluruh pelaku ekonomi memahami pentingnya pengelolaan sampah yang setiap hari dihasilkan maka pengelolaan sampah oleh pemerintah akan lebih mudah.

Pengelolaan sampah dapat dilakukan dengan cara teknologi atau dengan cara konvensional. Pengelolaan sampah dengan cara konvensional dapat dilakukan dengan menimbun sampah pada halaman rumah. Untuk wilayah daerah TK II yang tanahnya masih sangat luas dengan kepadatan penduduk sedikit dan sampahnya sebagian besar organik maka dengan cara dibuang di halaman belakang rumah masih merupakan penyelesaian yang ideal dan murah. (www.solusisampah.com). Pengelolaan sampah dengan cara teknologi sudah harus mulai diterapkan. Pengelolaan dengan cara teknologi masih sangat memerlukan peran pengelola sampah baik di rumah tangga maupun perusahaan. Pengelolaan sampah secara teknologi memerlukan biaya yang tidak sedikit untuk membeli teknologi yang digunakan untuk memproses 
sampah menjadi barang yang bermanfaat, misalnya sebagai pupuk, atau menghasilkan energi metan.

Program 3R (Reduce, Reuse, Recycle) merupakan program merubah perilaku dan pemahaman terhadap sampah yang dilontarkan oleh Menteri KLH Bapak Rachmat Witoelar di Ciroyom Bandung pada tanggal 9 September 2006. Program ini merupakan salah satu cara merubah perilaku masyarakat dalam memilah-milah sampah dimulai dari rumah tangga dan sektor-sektor informal. Selain memilah sampah hal penting lain yang dipahamkan adalah bahwa sampah dapat didayagunakan kembali (recycle) dan tidak perlu dibuang sembarangan. Apabila dikelola dengan baik akan bermanfaat bagi keluarga dan lingkungan. Jadi dasar pengelolaan sampah harus dilakukan secara terpadu mulai dari rumah tangga atau perusahaan, tukang sampah, dinas kebersihan dan pemerintah.

Sampah biasanya berasal dari berbagai kegiatan produksi yang dilakukan oleh berbagai sektor atau pelaku ekonomi baik pelaku rumah tangga, perusahaan maupun pemerintah. Para pelaku ekonomi tersebut dapat dilibatkan dalam proses pengelolaan sampah. Para anggota keluarga harus memiliki pengetahuan dalam memilah sampah sehingga akan memudahkan para tukang sampah yang akan membawa ke tempat pembuangan sampah sementara (dumpsite). Seluruh anggota keluarga terutama ibu merupakan pihak yang sangat memungkinkan untuk diajak turut serta memperhatikan kesehatan dan keindahan lingkungan khususnya pengelolaan sampah rumah tangga.

Perusahaan merupakan pihak yang juga andil dalam menghasilkan sampah baik sampah basah maupun padat. Bagian pengolahan limbah dalam perusahaan harus profesional dan benarbenar menjalankan fungsinya supaya tidak mencemarkan, seperti menimbulkan bau tidak sedap, mengganggu aliran sungai sampai polusi udara karena adanya pembakaran sampah besar-besaran. Dinas kebersihan yang mewakili pemerintah dalam mengelola sampah juga merupakan yang sangat penting dalam pengelolaan sampah. Dinas ini tidak sekedar mengumpulkan dan membuang sampah di tempat pembuangan akhir namun harus memiliki program pengolahan sampah agar sampah lebih bermanfaat. Pengolahan sampah agar bermanfaat tentu harus dikoordinasikan dengan berbagai pihak yang saling terkait seperti dengan para rumah tangga, tukang sampah, pengolah limbah perusahaan, dinas kebersihan, pengelola pembuangan sampah sementara (dumpsite) maupun pembuangan sampah akhir (landfill). Agar mereka optimal keterlibatannya dalam proses pengolahan sampah terpadu, pihak pemerintah kota harus mampu memberikan pengarahan yang tidak hanya berupa peraturan tentang cara pengelolaan sampah saja namun harus memfasilitasi tempat sampah yang membedakan antara tempat sampah untuk sampah basah dan sampah kering/padat. Apabila pengelolaan sampah tidak dilakukan secara baik maka biaya yang dikeluarkan akibat sampah akan semakin tinggi, seperti apabila menjadikan banjir, kesehatan lingkungan terganggu. Walaupun pengelolaan sampah membutuhkan biaya yang tidak sedikit namun dalam jangka panjang akan sangat bermanfaat. Pada tahun 2005, di Distrik Alberni-Clayoquot telah melakukan Perencanaan Manajemen Buangan Cair (SWMP, Solid Waste Management Plan) dengan jumlah biaya untuk daur ulang (recycling) bagi 30000 penduduk sebesar \$1000 (sumber: www.portaec.net).

Pengelolaan sampah sebaiknya dimulai dari rumah tangga, tukang sampah, dan selanjutnya diolah Dinas Kebersihan. Selanjutnya pemerintah yang bekerja sama dengan pihak perusahaan pengolahan sampah untuk mengolah sampah menjadi bermanfaat. Untuk sampai pada pengolahan sampah secara optimal terlebih dahulu disediakan tempat sampah basah dan kering. Namun demikian pendidikan dan pemahaman masyarakat terhadap pentingnya pengelolaan sampah menjadi bermanfaat harus disosialisasikan. Selanjutnya sosialisasi optimalisasi manfaat sampah juga harus dipahami masyarakat sehingga mereka dapat berperan dan terlibat dalam manajemen sampah kota secara keseluruhan. Oleh karena itu peran anggota keluarga dalam pengelolaan sampah tersebut sangat menarik untuk dikaji secara dalam mengingat rumah tangga sebagai pelaku pertama yang menghasilkan sampah rumah tangga (households waste). Peran anggota keluarga diharapkan sebagai kunci keberhasilan pengolahan sampah selanjutnya. Pengolahan sampah selanjutnya berkaitan dengan proses koordinasi pengelolaan sampah pihak-pihak terkait demi memperoleh suatu hasil tertentu misalnya sebagai sumber energi. Agar limbah sampah tidak 
menjadi masalah yang besar dan menyulitkan maka perlu dilakukan penelitian tentang "Analisis peran perempuan dalam pengelolaan sampah rumah tangga (studi pada masyarakat Kota Batu)".

Setelah penelitian dilakukan diharapkan dapat diperoleh berbagai manfaat antara lain dapat mengoptimalkan peran perempuan dalam mengelola sampah dari rumah tangga ke tempat pembuangan sampah, meningkatkan jiwa kewirausahaan dari pengelolaan sampah. Salah satu yang penting bagi kesehatan lingkungan karena dengan membantu menciptakan kesehatan dan keindahan lingkungan secara keseluruhan di kota Batu.

\section{METODE PENELITIAN}

Penelitian ini dilakukan di Kota Batu dengan unit analisis perempuan dalam keluarga. Adapun jumlah responden penelitian sebanyak 73 perempuan. Penentuan jumlah responden ditetapkan secara proporsional dengan jumlah keluarga pada tiga kecamatan yaitu kecamatan Kota Batu, Bumiaji dan Junrejo. Penentuan perempuan sebagai ibu dalam rumah tangga ditetapkan secara purposive.

Data yang diperlukan dalam penelitian berupa data primer yang diperoleh dengan menyebarkan daftar pertanyaan. Data sekunder diperoleh dari kantor kecamatan. Dengan wawancara terstruktur, tenaga lapang menyebarkan daftar pertanyaan terhadap perempuan dalam keluarga dan diperoleh 73 daftar pertanyaan yang lengkap. Jawaban dari daftar pertanyaan kemudian ditabulasikan dan dianalisis dengan bantuan program SPSS.

Untuk mengetahui peran perempuan dalam proses pengelolaan sampah keluarga digunakan alat analisis Harvard. Dengan alat analisis Harvard akan diketahui profil kegiatan perempuan dalam pengelolaan sampah, profil akses dan kontrolnya. Variabel penelitian mencakup tentang pengetahuan dalam pengelolaan sampah, kegiatan yang dilakukan, akses dan kontrol serta manfaat dan dampak dalam pengelolaan sampah.

\section{HASIL DAN PEMBAHASAN}

\section{Gambaran Daerah Penelitian}

Daerah penelitian ini adalah Kota Batu yang memiliki tiga kecamatan, yaitu Batu, Junrejo dan Bumiaji. Ketiga kecamatan tersebut memiliki jumlah penduduk sekitar 303.597 jiwa dengan topografi yang tidak jauh berbeda yaitu berada di lereng dan lembah dengan didominasi lereng. Jumlah penduduk yang demikian banyak menjadi tantangan sendiri dalam pengelolaan sampah rumah tangganya, terutama bagaimana mereka mengelola di daerah masing-masing.

Kecamatan Batu memiliki potensi yang sungguh luar biasa sebagai daerah wisata dan kota industri tanaman bunga. Junrejo memiliki potensi ekonomi yang sangat baik mengingat adanya berbagai sarana ekonomi dan perdagangan berbagai komoditas. Potensi perekonomian di Kecamatan Junrejo diukur dari potensi sarana ekonomi dan kegiatan ekonomi merujuk pada komoditas ekonomi yang terdapat di semua desa/keseluruhan dan kegiatan ekonomi yang dilakukan oleh penduduk setempat. Demikian juga kecamatan Bumiaji yang sangat berdekatan dengan kota Batu, memiliki potensi sebagai daerah wisata dan tanaman buah dan bunga.

Ketiga kecamatan tersebut memiliki potensi yang hampir mirip yaitu kaya akan tanaman buah dan bunga. Kedua jenis tanaman sangat subur dan terawat dengan baik sehingga memungkinkan ketiganya sebagai daerah wisata yang luar biasa indahnya. Ketiga daerah tersebut masih sangat menungkinkan untuk dikembangkan menjadi daerah wisata yang bertaraf internasional dengan terlebih dahulu diperbaiki infrastrukturnya. Salah satu bagian dari infrastruktur adalah pengelolaan sampah. Di ketiga daerah tersebut sudah kelihatan bersih dan segar namun masih perlu ditingkatkan pemahaman tentang pendidikan pengelolaan sampah dan dampaknya.

\section{Karakteristik Responden}

Responden penelitian ini berasal dari tiga kecamatan yaitu kecamatan Junrejo, Kota Batu dan Bumiaji. Jumlah responden keseluruhan sebanyak 73 keluarga.. Sebanyak 19 keluarga berdomisili di Kecamatan Junrejo, 18 keluarga di Kota Batu dan 36 orang di Kecamatan Bumiaji. Jumlah responden yang tidak merata karena jumlah keluarga pada tida kecamatan tersebut 
memang berbeda. Dari 73 responden tersebut yang menjadi unit analisis adalah perempuan (ibu dalam keluarga). Sebanyak 73 responden memiliki karakteristik pendidikan usia pekerjaan, pendapatan, jumlah anak, status perkawinan, lama kerja dan kepemilikan sarana kebersihan yang berbeda.

Dari 73 perempuan tersebut ternyata sebagian besar pendidikannya Sekolah Dasar $(38,4 \%)$, sebanyak 24 orang $(32,9 \%)$ memiliki pendidikan Sekolah Menengah Atas, 15 orang $(20,5 \%)$ memiliki pendidikan Sekolah Menengah Pertama, 4 orang (5,5\% memiliki pendidikan Sarjana Strata satu (S1) dan hanya 2 orang $(2,7 \%)$ memiliki pendidikan Diploma Dua (D2). Dengan pendidikan yang dimiliki tersebut, sebagian besar $(51,6 \%)$ mereka sekarang berusia lebih dari 41 tahun. Sebanyak 26 orang $(35,6 \%)$ berusia antara 31 sampai dengan 40 tahun. Sebanyak 11 orang $(15,1 \%)$ berusia antara 26 sampai dengan 30 tahun dan hanya 6 orang $(5,2 \%)$ berusia kurang dari 25 tahun.

Apabila dilihat dari jenis pekerjaan yang dimiliki responden ternyata sebanyak 18 orang (24\%) bekerja sebagai petani (bunga dan buah). Sebanyak 16 orang $(21,9 \%)$ bekerja sebagai pedagang (sayur dan buah), sebanyak 13 orang bekerja sebagai wiraswasta (warung makan, toko, warung kelontong). Sebanyak 6 orang sebagai Pegawai Negeri Sipil dan guru. Namun demikian ada yang tidak memiliki pekerjaan sebanyak 20 orang, mereka sebagai ibu rumah tangga. Dari 73 responden ternyata sebanyak masing-masing 4 orang $(5,5 \%)$ telah bekerja kurang dari 5 tahun dan antara 6 sampai 10 tahun. Sebanyak 19 orang (37\%) telah bekerja lebih dari 13 orang sebanyak 43 orang tidak menjawab karena lupa kapan mulai bekerja dan sebagian dari mereka adalah wiraswasta dan petani dan pedagang.

Dengan jenis pekerjaan seperti di atas, sebanyak 69 orang $(94,5 \%)$ memiliki pendapatan kurang dari Rp. 500.000,-. Dua orang (2,7\%) memiliki pendapatan antara Rp. 500.000,- sampai dengan Rp. 1.000.000,-. Hanya seorang yang memiliki pendapatan antara Rp. 1.500 000,- sampai dengan Rp. 2.000.000,- dan melebihi Rp. 2000.000,--

Dari 73 orang responden yang memiliki anak dua orang sebanyak 40 orang $(54,8 \%)$, yang memiliki anak antara 3 dan 4 sebanyak 26 orang $(35,6 \%)$. Sebanyak 3 orang $(4,1 \%)$ memiliki anak lebih dari lima. Diantara 73 responden sebanyak 4 orang tidak memberikan jawaban jumlah anak yang dimiliki. Dengan jumlah anak seperti tersebut di atas ternyata status perkawinan dari 73 responden sebanyak 11 orang $(15,1 \%)$ berstatus janda. Dengan demikian yang masih bersuami sebanyak 62 orang atau $(84,9 \%)$.

Dari 73 keluarga ternyata sebagian besar $(76,7 \%)$ telah memiliki tempat sampah dan ada di rumah mereka. Sebanyak 8 orang $(11 \%)$ di rumahnya tidak ada tempat sampah dan sebanyak 7 orang $(9,6 \%)$ ada tempat sampah yang menjadi milik bersama. Hanya dua orang yang tidak memberikan jawaban.

\section{Profil Pengetahuan Tentang Sampah}

Banyaknya responden yang mengetahui tentang bahaya sampah bagi kehidupan manusia akan menjadikan mereka lebih mampu dalam mengelola sampah paling tidak tidak membuang di sembarang tempat. Menurut 48 orang $(65,8 \%)$ menjawab bahwa sampah mengganggu kebersihan lingkungan jika tidak dikelola. Sebanyak 14 orang $(19,2 \%)$ menjawab mengganggu kesehatan, 2 orang menjawab menyebabkan penyakit kulit dan diare dan 5 orang $(6,8 \%)$ menjawab menyebabkan banjir. Secara keseluruhan dapat dilihat bahwa mereka memiliki pengetahuan tentang bahwa sampah berbahaya bagi manusia.

Dengan diketahuinya bahwa sampah bagi manusia ternyata para perempuan memiliki cara untuk menghindari bahaya sampah dengan membuang sampah pada tempatnya (63\%), membakar sampah $(16,4 \%)$, memilah sampah basah dan kering $(8,2 \%)$, dan hanya mengumpulkan sampah agar tidak berserakan sebanyak 5 orang $(6,8 \%)$. Sebanyak 4 orang $(5,5 \%)$ menjawab dengan berbagai cara di atas. Untuk itu dalam keluarga sangat diperlukan peran serta anggota keluarga untuk mengumpulkan sampah agar tidak berbahaya. Dari 73 perempuan ternyata 37 orang $(50,7 \%)$ mengatakan bahwa yang mengumpulkan sampah rumah tangga adalah para ibu dan 17 orang $(23,3 \%)$ mengatakan bahwa yang mengumpulkan sampah adalah ayah hanya 6 orang yang mengatakan bahwa yang mengumpulkan sampah adalah ayah dan ibu dan seorang mengatakan 
bahwa yang mengumpulkan sampah adalah anak laki-laki. Sebanyak 12 orang mengatakan bahwa yang mengumpulkan sampah tidak selalu ibu ayah atau keduanya, namun dilakukan secara bergantian.

Setelah sampah dikumpulkan sebaiknya harus dibuang dan dijauhkan dari tempat tinggal keluarga. Anggota keluarga yang berperan dalam membuang sampah menurut para perempuan antara lain ayah $(23,3 \%)$, ibu $(50,7 \%)$ ayah dan ibu $(8,2 \%)$, anak laki-laki $(1,4 \%)$. Menurut para perempuan sebanyak 29 orang $(39,7 \%)$ mereka membuang sampah ke tempat sampah, hanya 16,4 $\%$ mengatakan dibuang oleh petugas dan $17,8 \%$ mereka membuang dengan terlebih dahulu memasukkan sampah dalam kantong plastik.

Kesulitan yang dihadapi para perempuan dalam membuang sampah antara lain karena tempat pembuangan sampah yang jauh dari tempat tinggal mereka (50,7\%), bahkan ada yang tidak memiliki tempat pembuangan di rumahnya $(21,6 \%)$. Bagi mereka yang memiliki tempat sampah tentu tidak mengalami kesulitan karena ketersediaan peralatan tempat sampah (84,9\%), adanya petugas yang mengambil $(15,1 \%)$. Sebagian besar perempuan nampak tidak mengalami kesulitan dalam membuang sampah hal ini karena sebanyak 56 orang $(76,7 \%)$ karena sampah yang dihasilkan setiap hari kurang dari $2 \mathrm{~kg}$. Sebanyak 17 orang (23,3\%) menghasilkan sampah lebih dari $3 \mathrm{~kg}$ per hari.

Para petugas yang membuang sampah keluarga ternyata tidak langsung membuang ke tempat pembuangan sampah akhir. Sebanyak 35 orang (47,9\%) membuang sampah ke tempat pembuangan sementara dan ada yang membuang ke truk yang disediakan pemerintah $(28,8 \%)$. Sebagian kecil membuang langsung ke tanah kosong $(9,6 \%)$ dan ke sungai $6,8 \%)$.

\section{Profil Kegiatan Dalam Mengelola Sampah}

Sampah yang dihasilkan keluarga ternyata sebagian besar dari kegiatan memasak di rumah (74\%) dan berjualan serta membuat berbagai macam produk untuk dijual $(21,9 \%)$. Tempat kegiatan yang menghasilkan sampah adalah dapur (74\%), warung (13,7\%), tempat produksi $(8,2 \%)$. Waktu kegiatan yang menghasilkan sampah mulai pagi $(54,8 \%)$, sore $(8,2 \%)$ dan sepanjang hari $(34,2 \%)$. Cara yang dilakukan dalam membuang sampah, sebanyak 24 orang $(32,9 \%)$ dengan membuangnya ke tempat sampah yang tersedia, ke Selokan dan sungai $(13,7 \%)$, dikumpulkan ke dalam kantong plastik kemudian diambil petugas (45,2\%). Kegiatan mengumpulkan dan membuang sampah dilakukan pada waktu pagi hari $(50,7 \%)$, siang $(8,2 \%)$, sore $(24,7 \%)$.

Dalam mengumpulkan dan membuang sampah ternyata tidak semua perempuan memilahmilah sampah antara yang basah dan kering. Mereka langsung memasukkan sampah ke dalam kantong plastik (52,1\%), ke dalam keranjang bambu (21,9\%), ke dalam keranjang plastik $(6,8 \%)$. Namun demikian mereka masih ada yang memperhatikan sampah, barangkali terdapat sampah yang bermanfaat seperti kertas dan botol dapat dijual. Sebanyak 43 orang $(58,9 \%)$ mengatakan memiliki sampah yang dapat dimanfaatkan yang berupa kertas $(39,7 \%)$, botol plastik $(42,5 \%)$, botol kaca/gelas $(2,7 \%)$. Sampah yang tidak dapat dimanfaatkan umumnya berupa sampah sayur mayur $(9,6 \%)$. Sampah yang bermanfaat biasanya terlebih dahulu dikumpulkan baru dijual $(72,6 \%)$, ada beberapa yang langsung menjualnya (11\%), di daur ulang $(4,1 \%)$.

Untuk menghindari bahaya sampah sebagian besar telah melakukan kegiatan yang benar yaitu membuang sampah pada tempatnya $(60,3 \%)$, beberapa ada yang memilah sampah terlebih dahulu $(21,9 \%)$.

\section{Profil Akses dan Kontrol Dalam Mengelola Sampah}

Profil akses perempuan dalam mengelola sampah rumah tangga mencakup semua yang dilakukan dan bagaimana mereka dapat mengendalikan kegiatan dalam mengelola sampah rumah tangga. Dari 73 responden ternyata sebanyak 51 orang $(69,9 \%)$ setiap hari mengumpulkan dan membuang sampah rumah tangga. Sebanyak 10 orang (13,7\%) menyapu dan mengumpulkan sampah dan sebanyak 8 orang (11\%) hanya mengumpulkan sampah rumah tangga. Apabila mengalami kesulitan dalam membuang sampah mereka sebagian besar lapor kepada RT (50,7\%), sebanyak 10 orang $(13,7 \%)$ melaporkan ke petugas pengumpul sampah dan 6 orang $(8,2 \%)$ lapor 
kepada RW. Sebagian besar perempuan memilah antara sampah yang bermanfaat dan tidak. Sampah yang bermanfaat seperti kertas, botol plastik dan gelas dikumpulkan kemudian dijual setelah terkumpul banyak. Apabila para ibu mengalami kesulitan dalam mengumpulkan sampah meminta bantuan anggota keluarga dan atau petugas pengumpul sampah. Perempuan sebagian besar memiliki hubungan baik dengan petugas pengumpul sampah dan selalu menganjurkan pada anggota keluarga untuk mengumpulkan dan membuang sampah pada tempatnya sehingga memudahkan petugas.

\section{Profil Dampak dan Manfaat Dalam Mengelola sampah}

Dalam mengelola sampah perempuan akan memperoleh manfaat dari sampah yang dikelola dengan baik selain dapat dijual juga dapat di daur ulang seperti kertas dan botol plastik maupun botol gelas. Untuk itu menurut para perempuan sangat diperlukan pihak-pihak terkait seperti RT, RT, PKK dan pemerintah setempat. Peran PKK ternyata 56,1 \% sangat diperlukan dan sudah terjalin hubungan baik di antara warga PKK dalam memperhatikan sampah. Menurut mereka sampah dapat dimanfaatkan dengan didaur ulang $(32,8 \%)$ dan pemerintah yang melakukan $(21,9 \%)$ yang terlebih dahulu menyediakan tempat pembuangan akhir yang lebih luas $(26,4 \%)$. Sebanyak 43 orang $(58,9 \%)$ mengatakan memiliki sampah yang dapat dimanfaatkan yang berupa kertas $(39,7 \%)$, botol plastik 42,5\%), botol kaca/gelas $(2,7 \%)$.

\section{KESIMPULAN}

Dari hasil penelitian dapat disimpulkan bahwa peran perempuan terhadap pengelolaan sampah sangat diperlukan. Apalagi mereka sudah memiliki pengetahuan tentang bahaya sampah bagi kebersihan dan kesehatan lingkungan. Keterlibatan perempuan masih mendominasi pengelolaan sampah dalam rumah tangga. Pengelolaan sampah dalam rumah tangga mencakup kegiatan mulai dari menyediakan tempat sampah dan peralatan untuk mengumpulkan sampah, menyapu dan mengumpulkan sampah membuah sampah ke tempat sampah yang tersedia di rumah. Pengelolaan sampah dari rumah tangga ke tempat sampah di rumah dilakukan oleh ibu dan petugas pengumpul sampah yang membuang ke penampungan sampah sementara.

Profil akses dan kontrol perempuan dalam rumah tangga sering melakukan pemisahan antara sampah yang bermanfaat dan yang tidak, kemudian yang bermanfaat (kertas, botol plastik atau gelas) dikumpulkan sampai banyak dan dapat dijual, namun ada beberapa yang membuang begitu saja tanpa memisahkan, memberikannya pada pemulung. Kesulitan dalam membuang sampah akan dilaporkan pada Ketua RT atau RW. Namun yang penting perempuan sudah mampu untuk selalu menyarankan pada anggota keluarga agar membuang sampah pada tempatnya.

Profil dampak dan manfaat dari pengelolaan sampah adalah dapat terpilah pilahnya sampah antara yang bermanfaat dan tidak selanjutnya mereka dapat menjual sampah yang bermanfaat dan atau mendaur ulang. Dengan demikian mereka menginginkan adanya peran pemerintah khususnya dalam menyediakan lahan dan proses mendaur ulang.

Berdasarkan pada hasil penelitian di atas dapat disarankan bahwa setiap perempuan masih sangat perlu meningkatkan peranannya dalam pengelolaan sampah rumah tangga mengingat masih banyak laki-laki dan anak laki-laki yang belum terlibat. Para perempuan perlu mengajak mereka lebih berperan dalam mengurusi sampah rumah tangga. Melalui peran perempuan dalam PKK sangat dianjurkan lebih giat mensosialisasikan pentingnya pengelolaan sampah dimulai dari dalam rumah tangga (keluarga) kemudian perlu dikelola lebih lanjut oleh petugas pengumpul dan pembuang sampah ke Tempat Pembuangan Sampah akhir. Untuk itu sangat diperlukan peran serta para ketua RT dan RW untuk terlibat bersama-sama dengan pemerintah untuk mengusahakan pengelolaan sampah di luar rumah tangga sehingga lebih bermanfaat dan dapat menciptakan lapangan kerja baru untuk proses pendaur ulangan sampah (Garbage Recycling). 


\section{DAFTAR PUSTAKA}

Anonim. 1996. Mengidentifikasi Persoalan Perempuan. Editorial. Analisis Gender Dalam Memahami Persoalan Perempuan. Edisi 4. Bandung. Akatiga.

A, Gutek, Barbara. 1986. Women's Career Development. Newbury Park London New Delhi, Sage Publications.

Batty, Zarina. 1987. "Economic Contribution of Women to the household budget; a case study of beedi industry". New Delhi. Sage Publications India Pvt.

Dessler, Gary, Manajemen Manajemen Personalia, Penerbit Erlangga, Jakarta, 1995.

Hastuti, E.L. 2004. Pemberdayaan Petani dan Kelembagaan Lokal Dalam Perspektif Gender.. Pusat Penelitian dan Pengembangan Sosial Ekonomi Pertanian. Working Paper.

Hardyastuti, S. 1991. Pekerja Wanita, Pada Industri Rumah Tangga Sandang Di Propinsi Daerah Istimewa Yogyakarta. Pusat Penelitian Kependudukan Universitas Gajah Mada Yogyakarta.

Hull, Valerie. 1976. Women in Java's Rural Middle Class; Progress or Regress. Yogyakarta, Population Institute. Gajah Mada University.

Idris, M.Susrini. 2006. Mengenal Berbagai Teknik Analisis Gender. Sosialisasi Gender dengan Metode PROBA dalam rangka Pelaksanaan Pengarusutamaan Gender, Pusat Penelitian Gender dan Kependudukan Universitas Brawijaya Malang. Working Paper.

Lesser Blumberg, Rae. 1991. Gender Family and Economy; the triple overlap. Newbury Park London New Delhi, Sage Publications.

Lorber, Judith. 1991. The Social Construction of Gender. Newbury Park London New Delhi, Sage Publications.

Mae Kelly, Rita. 1991. The Gendered Economy, work, Career, and Success. Newbury Park London New Delhi, Sage Publications.

Magginson, David, 1993, Human Resource Development, PT Gramedia Jakarta, Jakarta.

Sekaran, Uma.1992. Research Methods for Business: A Skill Building Approach, United State of America: John Wiley \& Sons.

Singarimbun, Masri dan Sofian Effendi, Metode Penelitian Survei, Edisi Revisi, LP3S, Jakarta, 1989.

Umar, Husein, Riset Sumber daya Manusia, PT Gramedia Pustaka Utama, Jakarta, 1998.

Sekaran, Uma, Research Methods for Business : a Skill Building Approach, John Wiley \& Sons, United State, 1992.

www.solusisampah.com

www.portaec.net 